At-Turats

Jurnal Pemikiran Pendidikan Islam

journal homepage: http://jurnaliainpontianak.or.id/index.php/atturats

\title{
Internalisasi Nilai-Nilai Pendidikan Karakter pada Masyarakat Adat Dayak Ngaju
}

\author{
Gita Anggraini \\ STKIP Muhammadiyah Sampit \\ Kalimantan Tengah \\ gyt_ef@yahoo.co.id
}

\begin{abstract}
A B S T R A K
Character education has been a solution to resolve identity crisis for Indonesian young generation.excavation of original value from Indonesia has been a lot of tested and study.character education base local wisdom.Dayaknese Ngaju on Middle Borneo have recommendation values as character education enhancement.the study do on Pemantang village,East Kotawaringin District,Middle Borneo.the study using Qualitative Research Method,data collective:observation, interview and documentation.local wisdom embraced by the Dayaknese Ngaju on Middle Borneo is a philosophy of huma betang,habaring hurung,hatamuei lingu nalatai hapangkaja,karende malempang, the biggest love to the universe as the source of life. Internalized value process through paragon of the elders and indigenous, traditional events and enactment the Adat Law.
\end{abstract}

Key words: Internalized Value, Character Education, The Adat people

\section{PENDAHULUAN}

Pada dasarnya proses pendidikan merupakan usaha pewarisan nilai-nilai dari satu generasi kepada generasi berikutnya, dalam proses pewarisan tersebut di dalamnya juga terdapat upaya inovatif dan dinamik guna memperbaharui nilai tersebut ke arah yang lebih baik. Kepada pendidikan hampir semua komponen bangsa bersandar. Melalui dunia pendidikan diharapkan bangsa ini berdiri tegak dengan generasi-generasi berkarakter yang mampu memenangkan kerasnya persaingan global.

Tantangan dunia pendidikan semakin besar memasuki era digital. Generasi muda seakan hidup dalam media sosial, tegila-gila dengan "like" dan "followers". Kata-kata hujatan yang menghiasi timeline media sosial menjadi santapan kita sehari-hari, se- hingga muncullah istilah haters. Selain itu berita-berita yang belum tentu kebenarannya yang bergantian datang melalui group-group media sosial sering menjadi rujukan utama dalam berargumen. Sehingga tidak jarang memicu pertengkaran yang tidak terlalu penting. Bangsa Indonesia yang terkenal memiliki karakter santun, ramah, dan peduli seakan hilang. Pendidikan karakter yang didengungkan sejak bertahun-tahun lalu memang sangat diperlukan untuk membangun kembali karakter dan jati diri bangsa ini.

Pendidikan karakter merupakan pendidikan budi yang melibatkan aspek pengetahuan (cognitive), perasaan (feeling), dan tindakan (action) memiliki sembilan pilar karakter nilai-nilai luhur universal yang harus diwariskan, yaitu (1) Cinta tuhan dan kebenaran, (2) Tanggung jawab, kedisiplinan dan 
kemandirian; (3). Amanah; (4). Hormat dan santun; (5). Kasih sayang, kepedulian dan kerjasama; (6) percaya diri, kreatif dan pantang menyerah; (7). Keadilan dan kepemimpinan; (8). Baik dan rendah hati; (9). Toleransi dan cinta damai. ${ }^{1}$

Nilai-nilai-nilai tersebut harus terus menurus diinternalisasikan sehingga membentuk karakter. Lickona menyebut hal ini sebagai "A reliable inner disposition to respond to situations in a morally good way" atau sebuah kekuatan batin dalam menanggapi sesuatu secara bermoral. ${ }^{2}$ Karakter pada dasarnya menunjuk pada tiga hal yaitu moral knowing, moral feeling, dan moral behaviour. Lickona menambahkan bahwa karakter mulia (good character) meliputi pengetahuan tentang kebaikan, lalu menimbulkan komitmen (niat) terhadap kebaikan, dan akhirnya benar-benar melakukan kebaikan. ${ }^{3}$

Prof. Dr. Cece Rahmat dalam tulisannya "menyemai pendidikan karakter berbasis budaya dalam menghadapi tantangan modernitas" menyebutkan bahwa pembangunan karakter (character building) manusia Indonesia yang berpijak kepada khazanah nilai-nilai kebudayaan yang kita miliki adalah sebuah kebutuhan. Maka pengembangan pendidikan berbasis budaya Indonesia sudah seharunya mulai dikembangkan. Indonesia mempunyai begitu banyak kearifan budaya lokal yang menjadi nilai-nilai asli (local genuine) Indonesia dan telah teruji waktu. Nilainilai kearifan lokal tersebut telah berjasa membingkai Indonesia sehingga tetap utuh

Z.El Mubarok, Membumikan Pendidikan Nilai. (Bandung: Alfabeta, 2008), 111

2 Thomas Lickona, Pendidikan Karakter Panduan lengkap mendidik siswa menjadi pintar dan baik, terj. (Bandung: Nusamedia 2013).

3 Thomas Lickona, Educating for character: How our schools can teach respect and responsibility, (New York: Bantam, 1991) 51 dan kaya sebagai sebuah bangsa.

Salah satu suku terbesar di Indonesia dan memiliki kearifan lokal yang luhur serta karakter masyarakat yang kuat adalah adalah suku Dayak. Dayak adalah sebutan nama untuk menyebut penduduk asli di Kalimantan. Suku Dayak terdiri dari 7(tujuh) kelompok suku besar dan terbagi atas 405 sub suku kecil-kecil. Dari ketujuh kelompok suku, rumpun suku Dayak sebagian besar terdapat di kalimantan Tengah. Menurut Tjilik Riwut Suku Dayak di Kalimantan Tengah memiliki 54 sub suku yang tersebar di berbagai Aliran sungai yaitu sungai Kapuas, Kahayan, Katingan, Mentaya, Seruyan dan Barito. ${ }^{4}$ Suku Dayak yang paling umum di Kalimantan Tengah adalah Dayak Ngaju.

Tulisan ini mencoba menggali nilainilai kearifan lokal dan metode internalisasi nilai-nilai- tersebut pada masyarakat adat Dayak Ngaju di desa Pemantang Kabupaten Kotawaringin Timur Kalimantan Tengah. Melalui tulisan ini diharapkan dapat menjadi rekomendasi pengembangan nilai-nilai pendidikan karakter berbasis nilai-nilai lokal (local genuine) di Indonesia.

\section{KAJIAN TEORI}

Bertens ${ }^{5}$ menjelaskan pengertian nilai melalui cara memperbandingkannya dengan fakta. Fakta menurutnya adalah sesuatu yang ada atau berlangsung begitu saja. Sementara nilai adalah sesuatu yang berlaku, sesuatu yang memikat atau menghimbau kita. Fakta dapat ditemui dalam konteks deskripsi semua unsurnya dapat dilukiskan satu demi satu dan uraian itu pada prinsipnya dapat diterima oleh semua orang. Nilai berperanan dalam suasana

4 Tjilik Riwut, Kalimantan Memanggi (Jakarta: N.V. Pustaka-Penerbit \& Percetakan "Endang".1956)

5 Bertens, K.. Etika (Jakarta: Gramedia Pustaka Utama, 2007), 140 
apresiasi atau penilaian dan akibatnya sering akan dinilai secara berbeda oleh orang banyak. Nilai selalu berkaitan dengan penilaian seseorang, sementara fakta menyangkut ciri-ciri obyektif saja. Definisi lain tentang nilai dikemukakan oleh Richard Merril, menurutnya nilai adalah patokan atau standar pola-pola pilihan yang dapat membimbing seseorang atau kelompok ke arah satisfaction, fulfillment, and meaning.

Internalisasi nilai adalah penghayatan terhadap suatu ajaran, ajaran, doktrin, atau nilai sehingga menumbuhkan keyakinan dan kesadaran akan kebenaran doktrin yang diwujudkan dalam sikap dan perilaku. ${ }^{6}$ Internalisasi nilai dapat juga dimaknai sebagai upaya yang dilakukan untuk memasukan nilai-nilai ke dalam jiwa sehingga menjadi miliknya. ${ }^{7}$ Dalam menginternalisasikan nilai, Simon, Howe, dan Kirschenbaum dalam Wahab $^{8}$ menawarkan 4 (empat) pendekatan yang dapat digunakan, yaitu pendekatan penanaman moral, pendekatan transmisi nilai bebas, pendekatan teladan, dan pendekatan klarifikasi nilai.

Menurut Noeng Mohadjir yang dikutip oleh Muhaimin ada tiga tahapan dalam meinginternalisasikan nilai yaitu, (1) tahap transformasi nilai, pada tahap ini nilai hanya dinformasikan kepada orang atau individu-individu yang dinginkan baik secara verbal maupun non verbal; (2) tahap transaksi nilai, yakni suatu tahap internalisasi nilai dengan melakukan komunikasi dua arah atau interaksi antara subyek pemberi nilai dan obyek nilai

6 Pusat Bahasa Departemen Pendidikan Nasional, Kamus Besar Bahasa Indonesia (Jakarta: Balai Pustaka, 2003), 439

7 Fuad Ihsan, Dasar-dasar Kependidikan (Jakarta: Rineka Cipta, 1997) 155

8 Wahab Aziz. Pendidikan Pancasila dan Kewarganegaraan (PPKN). (Jakarta: Penerbit Universitas Terbuka, 2007) 123 yang bersifat interaksi timbal balik. Kalau dalam transformasi sosial interaksi masih bersifat satu arah maka tahap ini interaksi sudah menjadi dua arah dimana antara subyek dan obyek bersifat aktif. Tekanan dari komunikasi ini masih menampilkan sosok fisiknya belum mentalnya. Dalam tahap ini, pemberi nilai tidak hanya memberikan informasi tentang nilai-nilai yang baik atau buruk tetapi juga memberikan contoh dengan mengamalkan nilai-nilai tersebut. Sedangkan obyek diminta untuk memberikan respon yang sama, yakni menerima dan mengamalkan nilai tersebut. (3) Tahap transinternalisasi, yaitu tahap yang lebih dalam. Pada tahap ini pemberi nilai tidak lagi tampil dalam bentuk fisiknya melainkan sikap mental dan kepribadiannya. Oleh karena itu, dapat dikatakan dalam tahap ini komunikasi yang terjadi adalah komunikasi dua kepribadian yang masing-masing terlibat secara aktif.

Pada tahap transinternalisasi ini proses dimulai dari tahap yang paling sederhana sampai yang kompleks meliputi menerima (receiving) yaitu obyek bersedia menerima nilai-nilai baru yang dikembangkan dalam sikap afektifnya, menanggapi (responding) yaitu kesediaan untuk merespon nilai-nilai yang ia terima dan memiuliki kepuasaan untuk merespon nilai, memberi nilai (valuing) yaitu mampu memberikan makna baru terhadap nilai-nilai yang muncul dengan kriteria nilai yang diyakini kebenarannya, mengorganisasi nilai (organization of value) yaitu pengaturan berlakunya sistem nilai yang diyakini oleh subyek sebagai kebenaran dalam kepribadiannya sehingga ia memiliki satu sistem nilai yang berbeda dengan yang lainnya, karakteristik nilai (Characterization by a value or value complex) yaitu membiasakan nilai-nilai yang diyakini, dan yang telah diorganisisr dalam laku pribadinya sehingga nilai 
tersebut menjadi watak (karakter) yang tidak dapat dipisahkan lagi dari kehidupannya. ${ }^{9}$

Dalam konteks psikologi, internalisasi tidak lebih dari sebuah cara membangun dan mengembangkan dimensi-dimensi kejiwaan. Dengan bahasa lain, psikologi mendorong kesadaran kebatinan terhadap nilainilai tertentu agar diimplementasikan dalam kehidupan sehari-hari. Internalisasi nilai juga dipandang sebagai aspek-aspek dunia (khususnya aspek orang) di dalam diri rupa agar terjadi internalized yang diambil dari fungsi-fungsi eksternal. ${ }^{10}$ Pada akhirnya, dalam proses internalisasi nilai juga diperlukan penguat baik berupa reward maupun punishment.

\section{METODE PENELITIAN}

Penelitian ini dilakukan di desa Pemantang Kabupaten Kotawaringin Timur Provinsi Kalimantan Tengah pada bulan Juni 2016. Alas an pemilihan desa ini, karena masih kental dalam menjalankan kearifan lokal suku Dayak. Jenis penelitian adalah penelitian lapangan (field research), sedangkan metode penelitian menggunakan penelitian kualitatif karena permasalahan penelitian yang dikaji bersifat holistik, kompleks, dinamis dan penuh makna. Peneliti mencoba untuk memahami makna-makna sosial yang muncul dilingkungan obyek penilitian secara mendalam, berusahan menemukan pola, hipotesis dengan menggunakan teori untuk mengkaji obyek penelitian. ${ }^{11}$ Adapun pendekatan penelitian adalah etnografis. Peneliti mencari

\footnotetext{
Muhaimin, Pradigma Pendidikan Islam Upaya Mengefektifkan Pendidikan Islam di Sekolah (Bandung: PT Remaja Rosdakarya, 2004), 178-19

10 Djono, Intenalisasi Nilai dalam Pembelajaran, https://www.lyceum.id/internalisasi-nilai-pembelajaran/, diakses pada 10 Desember 2016)

11 Sugiyono, Metode Penelitian Pendidikan Pendekatan Kuantitatif, Kualitatif, dan R\&D (Bandung: Alfabeta, 2011), 285.
}

berbagai pola (mendeskripsikan sebagai ritual, perilaku sosial adat, atau kebiasaan) dari aktivitas mental kelompok tersebut yang direfleksikan melalui tindakan mereka yang diamati peneliti. Dengan kata lain peneliti mencari pola dari organisasi sosial dan sistem idesional. ${ }^{12}$ Pengumpulan data dilakukan dengan mendatangi tempat penelitian, observasi kehidupan subjek penelitian, wawancara dan dokumentasi.

\section{HASIL PENELITIAN DAN PEMBAHASAN}

Desa Pemantang merupakan salah satu desa yang ada di wilayah kecamatan Mentaya Hulu Kabupaten Kotawaringin Timur. Desa ini berjarak $\pm 30 \mathrm{~km}$ dari ibukota Kecamatan Mentaya Hulu yakni Kuala Kuayan dan $230 \mathrm{~km}$ dari bukota kabupaten Kotawaringin Timur yakni Sampit. Dengan luasan wilayah $\pm 20 \mathrm{~km}$ persegi. Secara geografis sebelah barat berbatasan dengan Kelurahan Kuala Kuayan, sebelah Timur berbatasan dengan Wilayah desa Tangar, sebelah utara berbatasan dengan desa Sapiri dan sebelah selatan berbatasan langsung dengan desa Rantau Umit.

Desa Pemantang berada di daerah aliran sungai Mentaya yang terbentang dari laut Jawa pada bagian hilir sampai dengan Kecamatan Antang Kalang pada bagian hulu dengan panjang $\pm 250 \mathrm{Km}$. Sungai Mentaya di kabupaten Kotawaringin Timur merupakan pintu masuk barang dan jasa yang utama melalui jalur laut untuk provinsi Kalimantan Tengah. Untuk mencapai desa Pemantang dapat melalui jalur sungai dan darat. Namun khusus untuk musim kemarau sering kali jalur sungai tidak dapat dilintasi, sedangkan

12 John W Creswell, Penelitian Kualitatif \& Desain Riset Memilih di Antara Lima Pendekatan (Yogyakarta: Pustaka Pelajar, 2014, 124-127 
jalur darat jika musim penghujan sangat sulit untuk dilewati. Hal ini disebabkan oleh jalan yang ditempuh menuju desa Pemantang sebagian besar masih berbentuk tanah kuning (belum diaspal), sehingga pada musim hujan jalan menjadi berlumpur. Jarak tempuh dari ibukota Kabupaten yakni Sampit sekitar \pm 4 5 jam melalui jalur darat dan \pm 6 jam melalui jalur sungai. Berdasarkan wilayah adat ${ }^{13}$ desa Pemantang berada di wilayah Kademangan ${ }^{14}$ Mentaya Hulu. Sedangkan kademangan Mentaya Hulu terdiri dari enam belas kerapatan Mantir Adat atau Let adat ${ }^{15}$ salah satunya adalah desa Pemantang.

Secara demografis penduduk desa Pemantang sebagian besar bermata pencarian sebagai petani. Mereka bertani di bidang perkebunan seperti karet dan kelapa sawit, sebagian lagi menanam padi atau ladang. Agama yang dianut sebagian besar penduduknya

13 Wilayah adat adalah wilayah satuan budaya tempat adat istiadat, kebiasaan-kebiasaan dan hukum adat dayak itu tumbuh dan berkembang, berlaku sehingga menjadi penyangga untuk memperkokoh keberadaan masyarakat adat yang bersangkutan (Peraturan Daerah Kabupaten Kotawaringin Timur Nomor 6 tahun 2012 Tentang Kelembagaan Adat Dayak Di Kabupaten Kotawaringin Timur Bab I pasal 1 ayat 26).

14 Kademangan adalah suatu lembaga adat dayak yang memiliki wilayah adat, kesatuan masyarakat adat dan hukum adat yang terdiri dari himpunan beberapa desa/kelurahan/kecamatan yang tidak dapat dipisah-pisahkan dalam wilayah kabupaten Kotawaringin Timur (Peraturan Daerah Kabupaten Kotawaringin Timur Nomor 6 tahun 2012 Tentang Kelembagaan Adat Dayak Di Kabupaten Kotawaringin Timur Bab I pasal 1 ayat 23).

15 Kerapatan Mantir adat atau let adat adalah perangkat adat pembantu damang atau gelar bagi anggota kerapatan mantir perdamaian adat di tingkat kecamatan dan anggota kerapatan mantir adat di tingkat desa/kelurahan, berfungi sebagai peradilan adat yang berwenang membantu damang menegakkan hukum adat dayak di wilayahnya (Peraturan Daerah Kabupaten Kotawaringin Timur Nomor 6 tahun 2012 Tentang Kelembagaan Adat Dayak Di Kabupaten Kotawaringin Timur Bab I pasal 1 ayat 24). adalah Kaharingan (agama asli suku Dayak). Pada zaman orde baru agama Kaharingan dimasukan menjadi salah satu aliran dalam agama Hindu. Sebagian kecil juga menganut agama Islam dan Kristen.

Penduduk desa pemantang masih memegang teguh nilai-nilai yang mereka yakini sejak dari nenek moyang mereka:

\section{Huma betang (Toleransi)}

Secara filosofis Huma Betang adalah nilai-nilai kebersamaan yang berarti bahwa manusia terikat pada masyarakatnya, manusia harus mengutamakan kepentingan masyarakat dari pada kepentingan pribadinya. Huma Betang sendiri merupakan rumah yang sangat besar dan tinggi mampu menampung beberapa kepala keluarga dalam satu atap. Pada zaman dahulu Huma Betang bagi masyarakat suku Dayak merupakan simbol dari toleransi dan solidaritas antara sesama manusia. Orang menempati rumah betang ini tidak mesti harus orang Dayak, bisa saja dihuni oleh penduduk diluar masyarakat Dayak.

Di dalam Huma Betang sendiri diterapkan beberapa aturan adat yang harus dipatuhi dan ditaati oleh penghuni untuk menjaga stabilitas antara penghuni. Huma Betang sendiri dipimpin oleh sorang pemangku adat atau dalam istilah suku Dayak disebut mantir adat ${ }^{16}$. Secara epistemologis huma betang berarti rumah yang besar, panjang dan tinggi. Untuk merawat dan memelihara rumah tersebut diperlukan kerjasama yang baik an-

16 Mantir adat adalah gelar tokoh masyarakat asli Suku Dayak yang mempunyai pengetahuan tentang adat istiadat dayak, kebiasaan-kebiasaan dan hukum adat dayak yang diakui oleh masyarakat, yang berkedudukan di Desa/Kelurahan (Peraturan Daerah Kabupaten Kotawaringin Timur Nomor 6 tahun 2012 Tentang Kelembagaan Adat Dayak Di Kabupaten Kotawaringin Timur Bab I pasal 1 ayat 25). 
tara sesama penghuni rumah seperti misalnya untuk mengurus, merawat dan membersih rumah dilakukan oleh kaum perempuan. Sedangkan kaum laki-laki bertugas untuk bertani, berkebun, berburu dan mencari kayu bakar. Di dalam rumah betang sendiri disediakan satu ruangan khusus yang berfungsi untuk menyimpan hasil pertanian untuk beberapa waktu kedepan sampai datangnya kembali musim panen berikutnya. Aturan yang berlaku didalam masyarakat adat Dayak sendiri penghuni Huma Betang tidak boleh lebih dari 41 kepala keluarga. Jika terdapat lebih dari 41 kepala keluarga maka dilakukan rapat adat yang bertujuan untuk mencari jalan keluar secara bersama-sama untuk menentukan siapa yang akan keluar dari rumah tersebut dan membangunan rumah betang yang baru. Dalam prakteknya pembangunan rumah betang yang baru tersebut tetap dikerjakan secara bersama-sama oleh masyarakat Dayak.

Filosofi Huma Betang sebenarnya mengajarkan untuk menjunjung tinggi nilainilai pluralisme dan kemajemukan serta tidak membeda-bedakan antara manusia. Dengan catatan perilaku manusia dalam berintegrasi tidak menyimpang dari norma-norma hukum adat yang berlaku bagi masyarakat Dayak.

\section{Habaring hurung (Kekeluargaan atau gotong royong)}

Habaring hurung berdasarkan padaan katanya dalam bahasa Indonesia adalah saling membantu. Namun makna mendalam yang terdapat dari istilah habaring hurung adalah menjunjung tinggi nilai-nilai kekeluargaan dan gotong royong untuk mencapai belom bahadat ${ }^{17}$. Secara filosofis tujuan

17 Belom bahadat adalah perilaku hidup yang menjunjung tinggi kejujuran, kesetaraan, kebersamaan
Habaring Hurung sebenarnya ingin membangunan masyarakat sipil yakni masyarakat yang memiliki peradaban yang baik, tinggi dan terpuji. Prinsip dasar habarung hurung menekankan pada pertolongan yang tidak boleh membedakan orang yang akan dibantu, baik berdasarkan status perekonomian mereka, sosial maupun garis keturunan.

Sikap kekeluargaan dan gotong royong yang diharapkan adalah terciptanya keseimbangan dalam alam manusia dan alam hatala ranying ${ }^{18}$ (Tuhan). Melalui semangat gotong royong masyarakat Dayak diharapkan tidak serakah, mengambil apa dari alam hanya sebatas kebutuhannya saja, sehingga masyarakat yang tidak mampu ikut merasakan. Maksud lain dari prinsip ini adalah agar masyarakat dapat memenuhi kebutuhan mereka secara berkelanjutan (sustainable), sepanjang tahun tidak mengalami kekurangan.

\section{Hatamuei lingu nalatai hapangkaja}

karende malempang (mengembarai pikiran dan perasaan satu dan lainnya saling mengunjungi)

Hatamuei lingu nalatai hapangkaja karende malempang adalah pemikiran tentang sifat-sifat kalunen (manusia) dalam hidup bermasyarakat, bertetangga, berbangsa dan bernegara. Sifat-sifat ini berupa sikap untuk saling menghargai, menghormati dan tidak mengecewakan/menyakiti anggota masyarakat yang lain. Bermasyarakat harus saling mengenal dan mengunjungi dalam situ-

dan toleransi serta taat pada hukum (hukum negara, hukum adat dan hukum alam). (Wawancara Parada, Mantir desaPemantang)

18 Hatala Ranying adalah Tuhan yang dipercayai oleh masyarakat suku dayak berdasarkan agama Kaharingan. Kaharingan sendiri adalah agama asli suku dayak dan pada masa pemerintahan orde baru dimasukkan menjadi sub rumpun agama Hindu atau yang dikenal dengan istilah Hindu Kaharingan. 
asi apapun seperti lagi ada musibah maupun ada pesta. Prinsip ini sebenarnya merupakan prinsip yang menekankan pada semangat solidaritas dan mengajarkan masyarakat untuk berempati dengan keadaan di sekitarnya (lingkungannya). Melalui ruang interaksi inilah kemudian antara sesama warga masyarakat suku Dayak bisa saling memahami sifat-sifat mereka dan mereka juga mempunyai mekanisme tersendiri dalam penyelesaian setiap permasalahan yang ada ditengah masyarakat. Jika pelanggaran yang dilakukan oleh masyarakat bertentangan dengan hukum adat Dayak maka orang yang melanggar akan dikenankan jipen ${ }^{19}$ berupa singer ${ }^{20}$.

\section{Menjaga dan melestarikan alam}

Menjaga dan melestarikan alam merupakan bentuk nilai-nilai lokal (local wisdom) yang masih dijunjung tinggi oleh masyarakat suku Dayak. Tujuannya adalah untuk menjaga keberlanjutan keseimbangan alam. Sebab menurut ajaran masyarakat suku Dayak jika manusia merusak alam maka mereka akan dimurkai oleh hatala ranying (Tuhan). Murka tuhan tersebut biasanya ditunjukkan

19 Jipen adalah hukum adat yang disanksikan kepada orang yang melanggar hukum adat dalam masyarakat dayak. Hukuman ini biasanya berupa denda maupun penyataan permohonan maaf secara terbuka kepada warga masyarakat adat dayak oleh pelanggar hukum adat tersebut. (Wawancara Rachmawaty, Pengurus Dewan Adat Dayak "DAD", Juni 2016)

20 Singer adalah bentuk dari hukuman yang disansikan kepada pelanggar hukum adat. Bentuk sangsi tersebut biasanya berupa benda-benda yang digunakan dalam upacara adat dayak. Namun singer ini sesuaikan dengan pelanggaran yang dilakukan. Jika pelanggarannya berat biasanya denda yang diberlakukan antara lain penyediaan heawan korban untuk upacara adat, balanga (Kendi yang besar), piring malawen (yakni piring yang terbuat dari bahan kuningan dan anti karat) maupun dalam bentuk yang lain. (Wawancara Rachmawaty, Pengurus Dewan Adat Dayak "DAD KT”, Juni 2016) dengan terjadinya peristiwa alam yang mengganggu kehidupan manusia seperti bencana banjir, musim kemarau yang berkepanjangan maupun wabah penyakit yang muncul akibat pengrusakan terhadap alam serta terbatasnya makanan manusia yang yang disediakan oleh alam baik kebutuhan yang berupa tumbuhan maupun hewan buruan.

Prinsip ini sebenarnya mengandung pesan moral bahwa sebenarnya manusia harus menghargai alam, tidak mengrusak alam, mengambil hasil dari alam seperlunya saja serta menjaga kelestarian alam. Sebab menurut keyakinan masyarakat suku Dayak jika merusak alam, maka ini merupakan awal dari terciptanya malapetaka bagi umat manusia. Jika murka hatala ranying tiba maka manusia tidak dapat membatalkannya.

Agar nilai-nilai tersebut senatiasa dijunjung tinggi dari generasi ke generasi maka masyarakat adat Dayak ngaju melakukan internalisasi nilai tersebut melalui pentauladan kaum tetua, pemangku adat atau langsung dipraktekan dalam kehidupan sehari. Selain itu internalisasi nilai juga melalui acara-acara adat yang masih sering dilaksanakan. Secara rinci proses internalisasi nilai kearifan lokal pada masyarakat adat Dayak Ngaju di desa Pemantang sebagai berikut:

1. Nilai-nilai Huma Betang masih terintegrasi dalam masyarakat suku Dayak pada masa sekarang dapat dilihat dari beberapa hal. Pertama, walaupun rumah tempat tinggal masyarakat suku Dayak tidak lagi satu atap yakni dirumah yang sangat besar dan dihuni oleh beberapa kepala keluarga. Namun nilai ini masih terasa sampai sekarang yakni dengan dibangunnya rumah masyarakat Dayak Ngaju yang saling berdekatan. Artinya rumah berada dalam satu kawasan tertentu dan proses pembangunan rumah itu sendiri dilakukan secara bersa- 
ma-sama. Apabila ada masyarakat membangunan rumah maka dengan sendirinya tanpa perlu perlu diarahkan masyarakat saling membantu. Kedua, budaya hakaja adalah kebiasaan saling mengunjungi antara sesama masyarakat suku Dayak Ngaju untuk mengetahui kondisi masyarakat lain maupun untuk sekedar saling bertukar informasi. Seperti tata cara bertani yang baik menurut pengalaman masing-masing, bahkan sampai merencanakan agenda aksi yang nantinya digunakan untuk bekerja secara bersama-sama.

\section{Kepercayaan terhadap kekuatan lain}

Para tetua adat menanamkan keyakinan kepada generasi berikutnya bahwa dalam setiap benda terdapat kekuatan yang tidak diketahui oleh manusia. Khususnya di pohon-pohon besar, hewan-hewan yang dikeramatkan, patung, batu yang besar, goa, teluk sungai dan tempat-tempat yang disucikan. Pada benda-benda tersebut selalu dipasang kain berwarna kuning. Menurut keyakinan masyarakat adat Dayak ngaju, kuning merupakan symbol keserasian antara alam, Tuhan dan manusia.

Tanda ini juga digunakan untuk memberikan peringatan kepada masyarakat agar tidak melakukan aktivitas-aktivitas yang dapat merusak ekosistem alam disekitar termpat yang disucikan tersebut. Menurut keyakinan mereka tempat-tempat seperti ini jika tidak dirawat akan membahayakan kehidupan manusia. Sejatinya kekuatan lain yang diyakini tidak dimiliki oleh manusia adalah kekuatan yang hanya dimiliki oleh Tuhan.

3. Penghormatan terhadap pohon, hewan dan alam

Penghormatan terhadap pohon yang dan hewan merupakan salah satu media yang dipergunakan oleh masyarakat suku Dayak ngaju dalam melakukan proses internaliasi nilai-nilai untuk melestarikan dan menjaga keseimbangan alam. Dalam kepercayaan masyarakat adat Dayak Ngaju pohon yang boleh untuk ditebang atau digunakan untuk kehidupan sehari-hari adalah pohon yang usianya sudah tua dan dilihat dari ukurannya pohon tersebut sudah besar. Namun tidak semua pohon yang besar dan tua dapat ditebang oleh masyarakat, ada beberapa pohon yang di sakralkan yakni upun lunuk ${ }^{21}$. Sedangkan hewan yang selalu digunakan oleh masyarakat adalah $h a-$ dangan ${ }^{22}$.

\section{Tradisi Bahandep ${ }^{23}$}

Melalui tradisi bahandep Sesama paraha$r i^{24}$ (saudara/keluarga) saling tolong menolong. Hingga saat ini bahandep masih dipertahankan. Saat musim tanam tiba, proses penggarapan mulai dari perbukaan lahan sampai dengan proses penanaman padi dilakukan secara bahandep.

21 Upun Lunuk adalah nama lain dari pohon beringin yang dipercayai oleh masyarakat suku dayak sebagai tempat yang sering dikunjungi hatala ranying (Tuhan), sangumang (malaikat laki-laki) dan sandak kamiak (malaikat perempuan/peri). (Wawancara Parada, Mantir desa Pemantang, Juni 2016)

22 Hadangan adalah nama lain dari Kerbau yang dipergunakan sebagai hewan untuk memberikan makan pada orang yang datang pada saat upacara adat.

23 Bahandep adalah cara penggarapan lahan perkebunan secara bersama-sama dan dikerjakanan secara bergiliran/bergantian. (Wawancara Rachmawaty, Pengurus Dewan Adat Dayak "DAD”, Juni 2016)

24 Pahari dalam bahasa dayak adalah saudara atau keluarga, saudara atau keluarga ini bisa keluarga inti yakni memiliki garis hubungan darah, maupun sesama warga masyarakat dayak dan etnis lain yang menghargai dan menghormati hukum adat dayak dapat pula dikatakan sebagai saudara/keluarga. 
Mekanisme bahandep dilakukan secara bergiliran berdasarkan kesepakatan yang telah mereka buat. Anggota masyarakat yang telah dibantu wajib hukumnya membantu yang lain sampai semua anggotanya selesai bertanam. Untuk menjaga kesuburan tanah, ranting dan pohon yang ditebang secara bersama-sama tadi kemudian dibakar. Agar api dari proses pembakaran ini tidak mengenai perkebunan warga lain, setiap warga wajib menjaga tepian lahan miliknya yang dibakar dan memadamkan api apabila merambat ketempat lain yang bukan lahannya. Sebagai bentuk terimakasih, warga yang lahannya sedang digarap secara suka rela menyiapkan makanan dan minuman untuk warga lainnya. Hasil pertanian juga disisihkan sebagian sebagai cadangan persedian beras masyarakat desa. Tujuannya jika musim panen berikutnya mengalami kegagalan maka mereka masih memiliki persedian bahan makanan. Prinsip ini dapat kita padankan dengan prinsip sedia payung sebelum hujan.

\section{Pemberlakuan Hukum Adat}

Hukum adat bagi masyarakat dayak merupakan salah satu media untuk menciptakan kepatuhan dalam menjaga nilai-nilai adat istiadat. Hukum adat memuat aturan-aturan atau kaidah-kaidah adat yang mengatur tata kehidupan dari suatu masyarakat sehingga hukum yang benar-benar hidup dalam kesadaran hati nuraninya. Hal ini tercermin dalam pola-pola tindakan mereka serta pola-pola sosial budayanya yang tidak bertentangan dengan kepentingan orang banyak.

Dalam masyarakat adat Dayak Ngaju hukum merupakan seperangkat norma, aturan dan ketaatan yang harus dipatuhi. Agar lebih mengikat, hukum adat juga mem- berlakukan sanksi-sanksi bagi yang melanggar. Sanksi dalam hukum adat Dayak Ngaju dikenal dengan istilah jipen. Agar terrhindar dari jipen sesama masyarakat harus saling menghormati dan menghargai. Hukum ini dalam masyarakat adat Dayak Ngaju di Desa Pemantang masih sangat kental terasa dan selalu dijaga oleh masyarakatnya.

\section{Memperkuat Peran pemimpin adat} Berdasarkan PERDA Kabupaten Kotawaringin Timur Nomor 6 tahun 2012 Tentang Kelembagaan Adat Dayak, Damang kepada adat dalam masyarakat Dayak mempunyai beberapa tugas yakni perta$m a$, menegakkan hukum adat dan menjaga wibawa lembaga adat kedamangan; membuat dan/atau menginventarisasi secara tertulis aturan-aturan dan/atau hukum-hukum adat serta hak-hak adat masyarakat Dayak. Kedua, menyelesaikan dengan cara damai jika terdapat perselisihan intern suku dan antara satu suku dengan suku lainnya yang berada di wilayahnya. Ketiga, memelihara, mengembangkan dan menggali kesenian dan kebudayaan asli daerah serta memelihara benda-benda dan tempat-tempat bersejarah warisan nenek monyang. Keempat, membantu pemerintah dalam pelaksanaan pembangunan dalam semua bidang, terutama bidang adat istiadat, kebiasaan-kebiasaan dan hukum adat. Kelima, memberikan kedudukan hukum menurut hukum adat terhadap hal-hal yang menyangkut adanya persengketaan atau perkara perdata adat jika diminta oleh pihak yang berkepentingan. Keenam, menyelenggarakan pembinaan dan pengembangan nilai-nilai adat Dayak, dalam rangka memperkaya, melestarikan dan mengembangkan kebudayaan nasional 
pada umumny dan kebudayaan Dayak pada khususnya. Ketujuh, mengurus, melestarikan, memberdayakan dan mengembangkan adat istiadat, kebiasaan-kebiasaan, hukum adat dan lembaga kedamangan yang dipimpinnya. Kedelapan, menegakkan hukum adat dengan menangani kasus dan atau sengketa berdasarkan hukum adat dan merupakan bentuk peradilan adat tingkat akhir. Terakhir, menjadi penengah dan pendamai atas sengketa yang timbul dalam masyarakat berdasarkan hukum adat. Memperkuat posisi pemimpin adat melalui perundang-undangan yang berlaku, merupakan upaya penguat dalam internalisasi nilai. Karena dengan memiliki legalitas, pemimpin adat dapat menindak upaya-upaya yang akan menggerus nilai-nilai lokal tanpa keraguan.

\section{PENUTUP}

Indonesia mempunyai banyak nilainilai asli (local genuine) yang bersumber dari kearifan lokal yang dapat dikembangkan dalam pendidikan karakter. Salah satu kearifan lokal yang dapat dikembangkan adalah nilai-nilai yang dianut oleh masyarakat suku Dayak Ngaju di Kalimantan Tengah. Nilainilai tersebut tecermin dalam filosofi huma betang yang mengajarkan nilai toleransi dan kebersamaan, habaring hurung mengandung makna gotong royong dan kekeluargaan, Hatamuei lingu nalatai hapangkaja karende malempang mengandung makna saling menjaga, menghargai, menghormati dan tidak mengecewakan/menyakiti. Serta kecintaan yang besar terhadap alam sebagai sumber kehidupan. Proses internalisasi nilai kepada generasi berikutnya dilakukan melalui pentauladan kaum tetua dan pemangku adat yang langsung dipraktekan dalam kehidupan sehari-hari. Selain itu internalisasi nilai juga dilakukan melalui acara-acara adat dan pemberlakuan hukum adat.

\section{REFERENSI}

Bertens, K.. Etika (Jakarta: Gramedia Pustaka Utama, 2007)

Djono, Intenalisasi Nilai dalam Pembelajaran, https://www.lyceum.id/internalisasi-nilai-pembelajaran/, diakses pada 10 Desember 2016)

Fuad Ihsan, Dasar-dasar Kependidikan (Jakarta: Rineka Cipta, 1997)

John W Creswell, Penelitian Kualitatif \& Desain Riset Memilih di Antara Lima Pendekatan (Yogyakarta: Pustaka Pelajar, 2014)

Muhaimin, Pradigma Pendidikan Islam Upaya Mengefektifkan Pendidikan Islam di Sekolah (Bandung: PT Remaja Rosdakarya, 2004)

Peraturan Daerah Kabupaten Kotawaringin Timur Nomor 6 tahun 2012 Tentang Kelembagaan Adat Dayak Di Kabupaten Kotawaringin Timur

Pusat Bahasa Departemen Pendidikan Nasional, Kamus Besar Bahasa Indonesia (Jakarta: Balai Pustaka, 2003)

Sugiyono, Metode Penelitian Pendidikan Pendekatan Kuantitatif, Kualitatif, dan $R \& D$ (Bandung: Alfabeta, 2011)

Thomas Lickona, Pendidikan Karakter Panduan lengkap mendidik siswa menjadi pintar dan baik, terj. (Bandung: Nusamedia 2013)

Thomas Lickona, Educating for character: How our schools can teach respect and responsibility, (New 
York: Bantam, 1991)

Tjilik Riwut, Kalimantan Memanggi (Jakarta: N.V. Pustaka-Penerbit \& Percetakan "Endang".1956)

Wahab Aziz. Pendidikan Pancasila dan Kewarganegaraan (PPKN). (Jakarta: Penerbit Universitas Terbuka, 2007)

Z.El Mubarok, Membumikan Pendidikan Nilai. (Bandung: Alfabeta, 2008)

Rachmawati (Pengurus Dewan Adat Dayak), wawancara, Juni 2016

Parada, Mantir desa Pemantang, wawancara, Juni 2016. 